
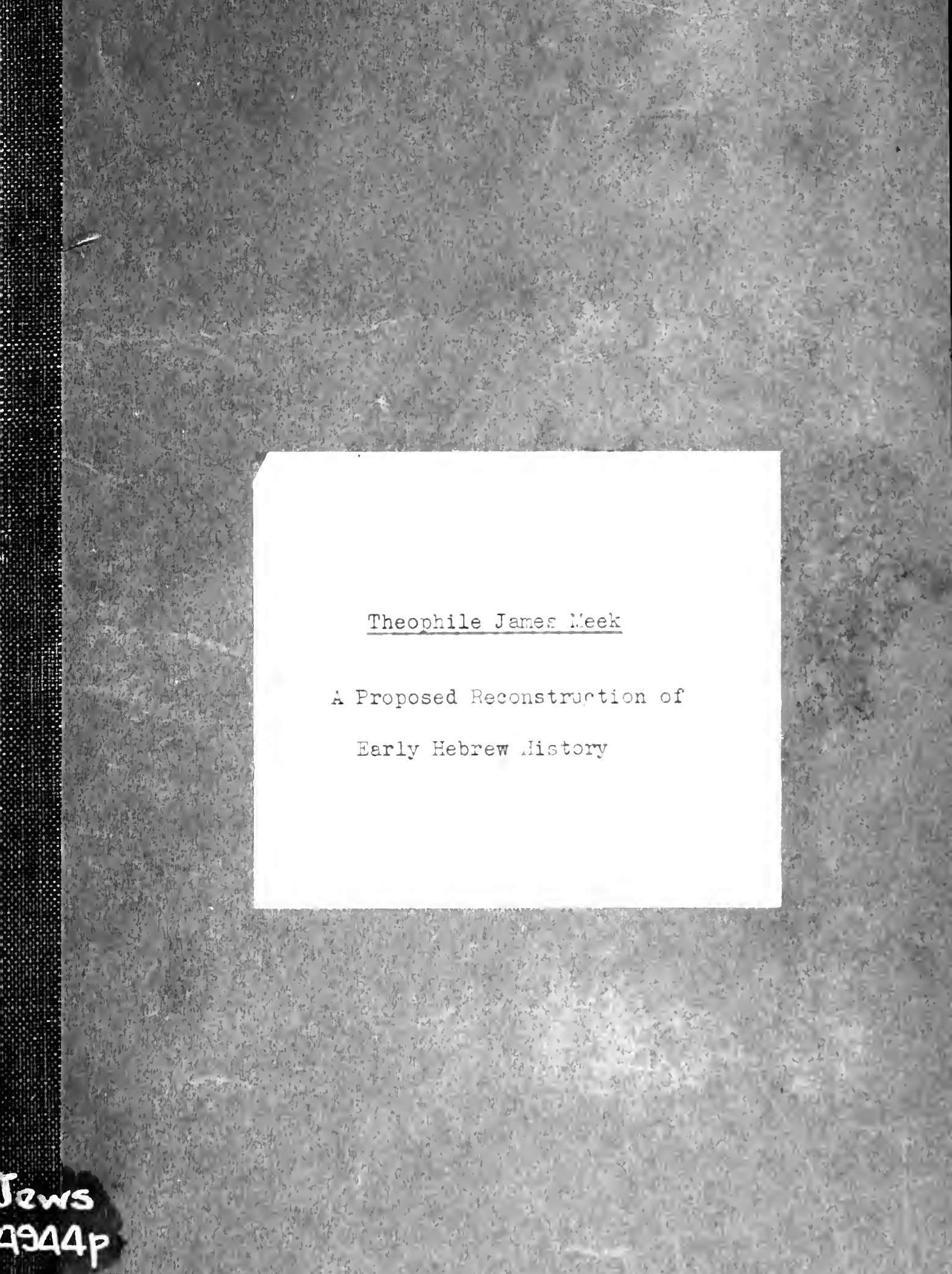


Digitized by the Internet Archive in 2007 with funding from

Microsoft Corporation 


\section{A PROPOSED RECONSTRUCTION OF EARLY HEBREW HISTORY ${ }^{\mathrm{x}}$}

THEOPHILE JAMES MEEK

Meadville Theological School, Meadville, Pennsylvania

In the fifteenth century before Christ there came surging into the westland great and numerous hordes of peoples, largely of Aramean stock. These are the Habiri or SA-GAZ peoples of the Amarna letters. Palestine was naturally one of the lands that attracted the attention of these migrants, but it was no easy task to dispossess the Canaanitish population that had been long resident in the country. Some of the invaders, however, under the leadership of Hoshea, later known as Joshua, ${ }^{2}$ were able to wrest a part of the land from the Canaanites and in the Amarna period we find them in possession of such cities as Jericho, Gilgal, Shechem, Gibeon, Shiloh, Mizpah, and Bethel. Other cities in the neighborhood like Akko, Megiddo, Gezer, Askalon, Lachish, and Jerusalem could not be reduced and from these we have urgent appeals to the Egyptian king for help against the invaders. The newcomers in the land were a more or less composite group, but their common cause against a common foe quickly united them and in due course a confederacy of these northern tribes was organized by Hoshea at Mount Gerizim near Shechem. Here a covenant was made, a simple code of laws promulgated, ${ }^{3}$ and a loosely organized state established, modeled

${ }^{x} \Lambda$ paper read before the meeting of the Society of Biblical Literature and Exegesis in New York, December 29, I919. This paper has grown out of the effort to answer some of the problems raised by Neyer and Luther in their Dic Isracliten und ihre Nachbarstämme; by Luckenbill in his article, "On Israel's Origins" (American Journal of Theology, XXII, 24 II.); and by J. M. P. Smith in his articles, "Some Problems in the Early History of Hebrew Religion" (AJSL, XXXII, 8r if.), and "Southern Influences upon Hebrew Prophecy" (AJSL, XXXV, 1 ff.). To all of these writers I am naturally much inclebted.

${ }^{2}$ Num. 13:16; cf. Num, 13:8 and Deut. 32:44, where Joshua is called Hoshea.

${ }^{3}$ The original of this code is probably to be found in the curses of Deut. 27; cf. Mleyer and Luther, op. cil., pp. 542 ff. 
more or less after the pattern of the Canaanitish state and incorporating in it some Canaanitish and other foreign elements. In this northern confederacy we have the beginning of what is later to be known as Israel.

While these northerners were carving out for themselves a home in the land of Palestine, the mass of the migrating hordes had perforce to seek home and pasturage elsewhere. The push was westward and in that direction they continued, dropping off fragments on the way that come later to be known in history as the Ammonites, Moabites, Edomites, Amalekites, Kenites, etc. Some of the more venturesome spirits, however, pushed their way to the very borders of Egypt and eventually settled in the land of Goshen, where under a benevolent government they grew and prospered. But with the overthrow of the Eighteenth Dynasty their happy lot changed to one of oppression, till a deliverer arose in the person of Moses, about I 200 B.C., soon after the death of Merneptah. Under his leadership and in the name of their tribal god, Yahweh, they saved themselves by bounding back to the desert, with whose spirit they were still more akin than with that of the more cultured Egyptians. They accordingly retraced their earlier steps and mingled again with their kinsmen whom they had left behind in the Negeb. The Negeb, never able to support a large population, was filled to overflowing with this inrush of newcomers and a part of this enlarged population had of necessity to seek a homeland elsewhere. Sensing the opportuneness of the occasion, Moses put himself at the head of this overflow, and probably following the earlier example of Hoshea in the north, and possibly in some respects improving upon it, organized his followers into a confederacy; made the old tribal god, Yahweh, the god of the confederacy, and in his name made a covenant with the people; and proceeded to collect and codify the various laws, customs, and traditions of the tribes into one confederate code. Under the stimulus of his leadership and personality the confederate tribes gradually pushed their way to the north, from Horeb and Kadesh, to Beersheba, to Hebron; till finally they controlled most of the land south of the northern confederacy between Philistia and the Dead Sea. Indeed they seemed to have wrested a part of 
this southern country from the northerners, because shortly before this time Israel is referred to on the Merneptah stela as occupying territory fairly well to the south. These southerners are the people later known as Judah.

This reconstruction of early Hebrew history is offered on the ground that it best agrees with the facts at present known with regard to this early period.

I. In the first place it accords with the generally accepted theory that the Hebrews were of Aramean origin. This is the testimony of history, archeology; philology, and ethnology; and it is likewise the unanimous native tradition of the Hebrews themselves, e.g., Gen. 29:10 (J), 3I:20 (E), 25:20 (P); Deut. 26:5 (D).

2. To connect the Hebrews with the great migratory westward movement of the Amarna period would seem best to agree with the evidences of the Amarna letters and the Old Testament narrative. As Böhl, Kanaanäer und Hebräer, pp. 67 f., has pointed out, we probably do not have letters in the Amarna collection from Jericho, Gilgal, Shechem, Gibeon, Shiloh, Mizpah, and Bethel as we do from neighboring towns because they were doubtless by this time in the hands of the invading Habiri. Also, the excavations at Jericho indicate the Amarna period as the latest date for the destruction of that city. ${ }^{x}$ Likewise, much of the biblical data would suggest the same period, as for instance, I Kings $6: \mathrm{I}$, which dates the Exodus and therefore the conquest of Palestine 480 years before Solomon's temple; Judg. I I $: 26$, which indicates 300 years as the length of Israel's occupation of the East Jordan up to Jephthah's day; Gen. 36:3I-39, which names eight Edomite kings between the time of Moses and Saul.

3. To put the settlement of Israel in the north two hundred or more years before that of Judah in the south would seem best to account for the cultural superiority of the north over the south. Two hundred years earlier settlement in agricultural life and closer and more intimate contact with the cultured Camanites would give the northerners no little advantage over their kinsmen to the south.

4. The settlement of the two groups at different periods and under different leaders, and with differences in cultural and religious

${ }^{`}$ Sellin und Watzinger, Jericho, p. I $8_{\mathbf{I}}$. 
attainments, would seem to account best for the continued friction between them through the whole course of history. Only for a brief period were they ever united and then only temporarily, while engaged in a common cause against a common foe, the Philistines. When this pressure was removed, their differences quickly reappeared, till finally they split permanently into their separate kingdoms. Israel, for the time being at least, reverted to the old bull-worship and the like, thereby severing herself from the south religiously as well as politically.

5. The hypothesis that Yahweh was more or less known to all the tribes but was originally the tribal god of one of the southern group, probably the tribe of Judah, later by Moses to be made the god of the confederacy, would seem best to accord with what we know of Yahwism. According to J, our oldest and probably most reliable source, it was not a new god at all but a god long known to the Hebrews, under whose guidance Moses brought the people out of Egypt (cf., e.g., Exod. 3: 16-I8). E likewise affirms (Exod. 3: 15) that the god who appeared to Moses was the same god whom his fathers, Abraham, Isaac, and Jacob, worshiped. It seems to imply, however, that he was now revealed under a new name, for from this point onward E's preference for Elohim as against Yahweh disappears. Of our sources $\mathrm{P}$ alone (the least 1rustworthy) dissents therefrom (Exod. 6:2 ff.). That a god in the first instance rather obscure, but nevertheless more or less generally known to the whole group, should eventually rise to the position of chief god and then sole god, has many parallels in the history of religions (as for instance Allah, Ahura-Mazda, Chiva, and Vishnu); whereas P's contention (likewise that of some modern scholars), that Yahweh was absolutely unknown to the Hebrews until he was introduced to them by Moses, is altogether without parallel and is exceedingly difficult, if not impossible, to conceive. Yahwism seems to have got an earlier and a much better hold in the south than in the north. Yahweh, in name at least, may have been known to the northerners, but the cult was doubtless of southern origin. The Levites seem to have been its propagandists and they were apparently from the south and are seemingly connected with Moses (Exod. 2:1; 6:16-20; Judg. 18:30). It was through their 
propaganda and the more vigorous efforts of the earlier prophets ("the sons of the prophets" of the book of Samuel), the Nazarites and the Rechabites, that Yahweh came to be made a national goda propaganda to which the north never took very kindly. Their earlier tribal gods and the gods that they borrowed from their neighbors seem to have been more to their liking than the confederate god of their southern kinsmen. When the later prophets (nearly all of them of southern blood, it will be noted) were able through some of their number to persuade Israel to at least a partial recognition of Yahwism, a long step had been taken in the direction of making Yahweh an international god or universal god, in that we have now what are essentially two distinct nations worshiping one and the same god in very much the same way. ${ }^{\mathrm{r}}$

To my mind Luckenbill has conclusively shown ${ }^{2}$ that Yahweh is not found in cuneiform literature until the eighth century B.c. and so was not the universally known god that Assyriologists were at one time wont to contend. At best he was known probably little more than by name to most of the Habiri tribes as the tribal god of one of their number. In confirmation of this it might be noted that the two extra-biblical names of the eighth century which contain the Yahu compound (Ya'u-bidi, king of Hamath, and Azri-Ya'u, king of Ya'udi) are Aramean, and further it is to be noted that in the list of gods of Ya'udi given in the Hadad inscription, the god Yahu does not appear. ${ }^{3}$ According to our hypothesis Yahweh does not become the national god of the Hebrews until about the time of David when north and south were temporarily united, and this is confirmed by a study of Hebrew proper names, which shows that Yahweh compounds, in the forms Yah and Yahu, are very rare before the time of David, whereas after that time they appear with ever-increasing frequency, until in the days of the later prophets they are very common. ${ }^{4}$

${ }^{x}$ Cf. further on this point J. M. P. Smith, "The Effect of the Disruption on the Hebrew Thought of God," $A J S L$, XXXII, 26I If.

'AJTh, XXII, $47 \mathrm{ff}$.

3 Cf. Meyer, op. cil., pp. 247 f.

4 See Gray, Shudies in Ilebrew Proper Names, pp. $257 \mathrm{ff}$; and Smith, AJSL, XXXV, I5. 
6. The contention that only a part of the Hebrews ever went to Egypt seems best to agree with the known facts in the case. According to J (e.g., Exod. I : ro) the Hebrews constituted a comparatively small community. According to E (Exod. I:I5) they were so few that two midwives were sufficient for them, and even $P$ holds that only seventy went down to Egypt (Gen. 46:27). The land of Goshen even today can support only a small population, and the wanderings of the Hebrews through the wilderness would be quite impossible for a large number. Nomadic bands are never large. The genealogies of I Chron. I-8 ignore the Exodus altogether, and that would suggest that some of the Hebrews never left Canaan-so also Gen. 38. The Pentateuchal narratives presuppose that Kadesh was already in the hands of the Hebrews at the time of the Exodus. Judges II:26 affirms that they had been living in certain cities in Canaan for 300 years, and this would carry us back to a period long before the Exodus. A people by the name of Habiri (variant, SA-GAZ) are frequently mentioned in the Amarna letters as overrunning the land of Canaan. By practically all scholars this people is regarded as one with the Hebrews, i.e., it was a portion of the larger group of peoples of which the Hebrews were another part. Seti I (ca. I3 I0 B.c.) in one of his inscriptions mentions a certain Shasu people in Canaan, and this people we know from other sources is identical with the Habiri. Seti I and Ramses II mention the tribe of '-s-r (identified by most scholars with Asher) as settled in north Canaan, and there are evidences in the Amarna letters to the existence of Asher at that time. This tribe was later adopted into the Hebrew confederacy and probably belonged to the same general stock. Gad, another of the Hebrew tribes, is referred to by Mesha in his inscription as an early inhabitant of Canaan. Zilpah and Bilhah, the mothers of four of the later tribes of Israel, are said by the biblical narrative to have been concubines, which shows that these tribes were of alien origin. This is most easily explained as an absorption of Canaanite, or possibly earlier Hebraic, elements. On the Merneptah stela ( $c a$. I 225 B.C.) there appears the word "Israel" as the name of a tribe in Canaan, which is of course clear evidence for the presence of the Hebrews there at that time, and the Exodus 
had probably not as yet taken place. All the evidences, then, would seem to indicate that there were Hebrews in Canaan during all the time that there were Hebrews in Egypt and that only a part, and evidently a small part, of the people ever went to Egypt. ${ }^{\mathrm{r}}$

7. The point that will probably meet with most objection is the placing of Hoshea or Joshua before Moses, which at first sight would seem to be so out of accord with the biblical narrative. For the detailed argument in favor of this I would refer you to the discussion of Luther and Meyer in Die Israeliten und ihre Nachbarstämme, pp. $542 \mathrm{ff}$. What Hoonacker, Kosters, Torrey, and others have done for the relationship of Ezra and Nehemiah, Luther and Meyer, followed by Luckenbill and Smith, are doing for that of Moses and Joshua. ${ }^{2}$ An ever-increasing number of scholars are today agreeing that Nehemiah is to be placed before Ezra. 'So eventually, I believe, critical opinion will agree to the placing of Joshua before Moses. This would seem to be the better interpretation of the biblical narratives. Numerous passages in the Old Testament show that Shechem was intimately associated with law-giving and was the political and religious center of the north, even as it is for the Samaritans down to the present day. Shechem was the home of the old Ba'al-berith or El-berith (lord or god of the covenant). Here stood the "oak of the law-giver" (Gen. I $2: 6$, and elsewhere), and "the oak of the soothsayers" (Judg. 9:37); and it is at Shechem that Joshua's law-giving and covenant-making are staged in the books of Deuteronomy and Joshua. Hence it is not surprising to find scholars suggesting that Shechem was the original home of the Hebrew Torah, as over against Horeb-Sinai or Kadesh, in that the Shechem story is manifestly the earlier. Indeed some, as for instance Holzinger, Staerk, Steuernagel, and Luckenbill, would go so far as to suggest that the Book of the Covenant (Exod. 20:22-23:19) in whole or in part originally stood in Joshua, chapter 24 , constituting "the book of the law of God" mentioned in verse 26 . The story of the double giving of the Toral, first by

"For a fuller discussion of this see Pitton, Biblical World, XLVI, 82-8S.

${ }^{2}$ It ought to be noted that Meyer does with Moses what Torrey does with Ezra: he makes him a figment of the priestly imagination and so denies him historicity, op. cit., p. 45I, note $\mathrm{I}$. But Luther does not do this, nor is it necessary to our hypothesis. 
Moses at Sinai (Exod. I9 ff.) and later by Joshua at Gerizim (Josh. 8:30 ff.; 24; cf. Deut. II:29; 27), as suggested by the Old Testament narrative, is open to grave suspicion and would seem to be the result of a prejudiced Judean interpretation of the events, because it is of course natural that the Judeans would not take kindly to Israelitish precedence in law-giving. We need to remember that our Old Testament narrative has come to us through Judean rather than Israelitish hands and of course in the very nature of the case is decidedly Judean in its interpretation of history. In the present instance this is clearly shown by the Judean alterations of the text in three of the passages cited, Deut. II:29 f.; 27:4; Josh. 8:30. In the first passage that part of verse 30 which would seem to locate Gerizim somewhere near Jericho is manifestly a gloss; and in the two other passages Ebal has very plainly been substituted for Gerizim.

Early Hebrew law is shot through with Babylonian influences, as Johns has well shown in his Schweich lectures, ${ }^{\mathrm{I}}$ and this dorbtless came about, not through direct contact with the Babylonians, but rather through the Canaanites, and that contact was in the north rather than in the south.

There was a time when scholars were inclined to put most of Hebrew law in the late period and refused to allow more than a fragment to the time of Moses. But much of the law is comparatively primitive in character and surely did not require the hundreds of years for its development that scholars used to postulate, particularly when the Hebrews were living in close and familiar relations with the cultured Canaanites. Other peoples, living in less propitious surroundings, did not take any great while to develop their early codes. Hence, instead of putting most of Hebrew law long after Moses we would assign much of it to a period before Moses and make Hoshea one of its earliest compilers.

The Hebrew people are composite in origin and behind the other elements there clearly stand out the Israelitish and Judean strains. Each of these made its contribution, Israel along cultural lines, Judah along religious lines, to the sum total of that magnificent heritage of culture and religion that contributed so largely to the enlightenment of the world.

${ }^{1}$ The Relation between the Laws of Babylonia and the Laws of the Hebrew People. 



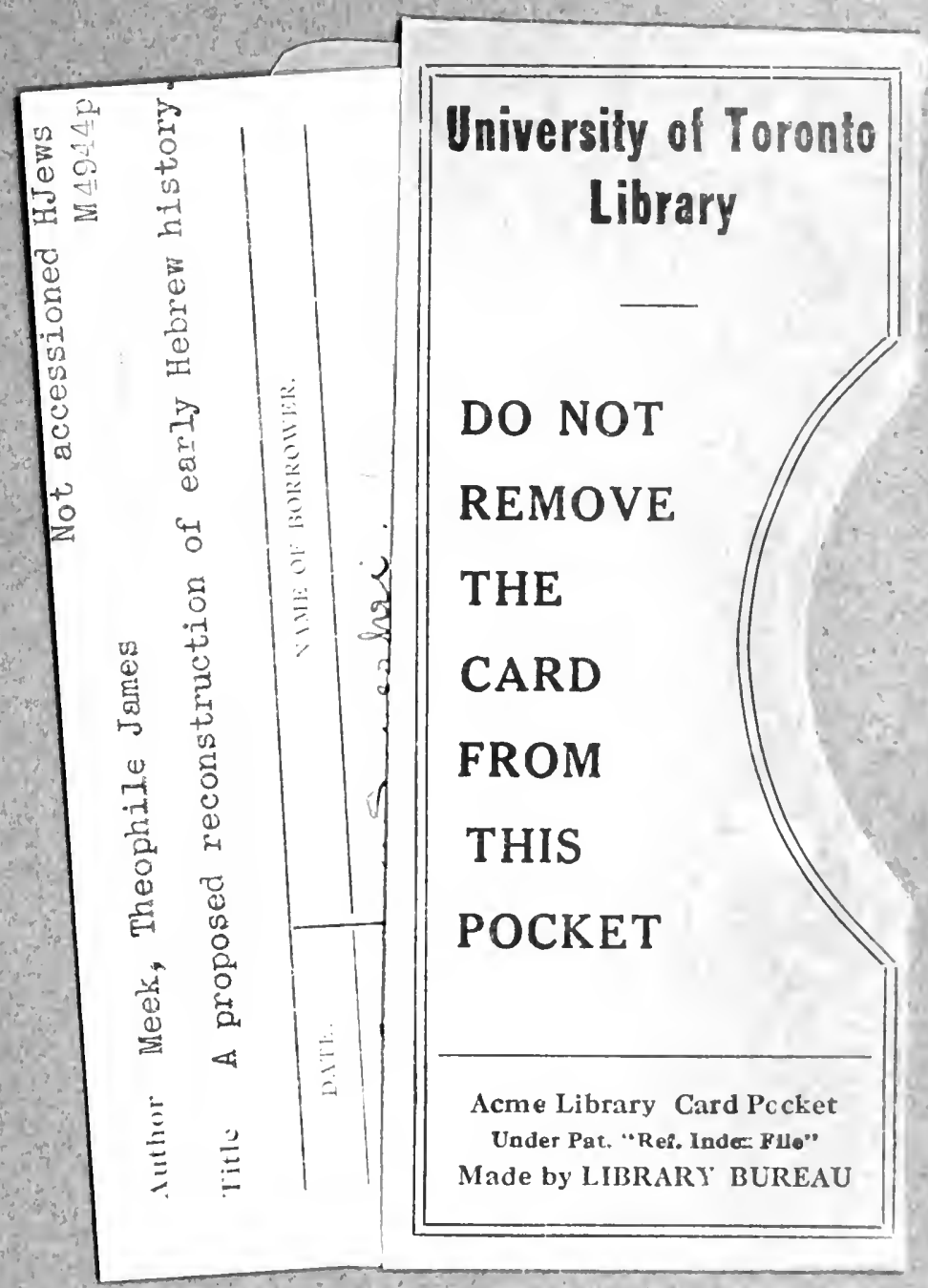


HW

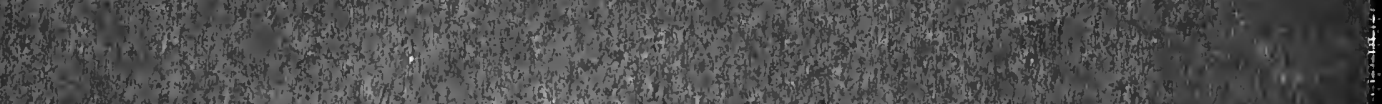

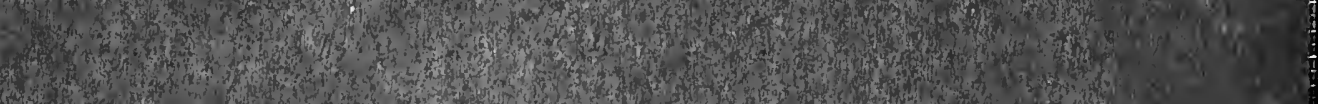
1.

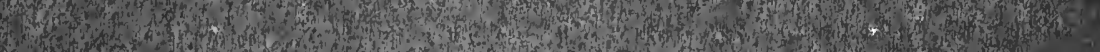

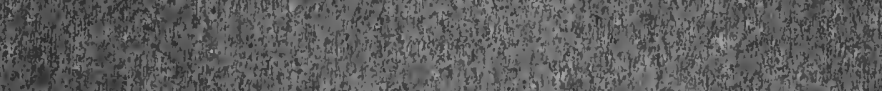

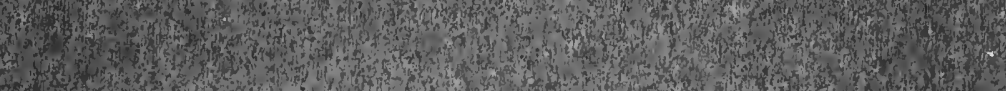
(1)

i.t.

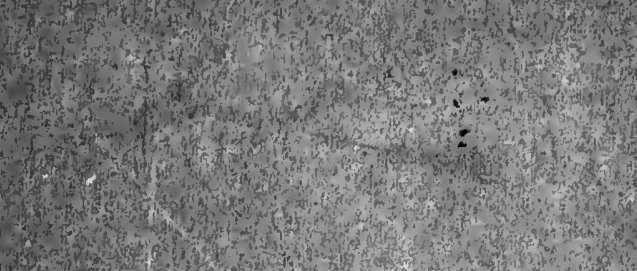

(2.)

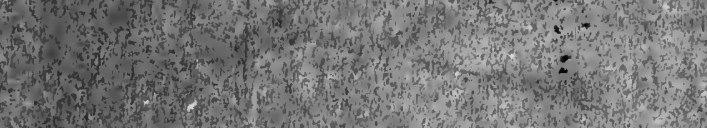

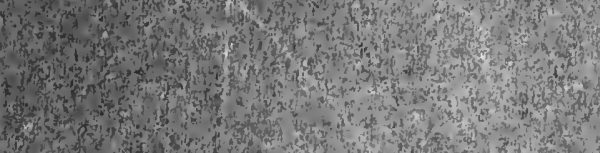
13
4

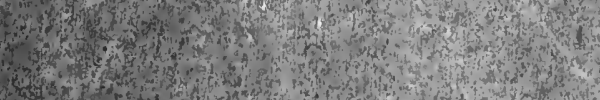

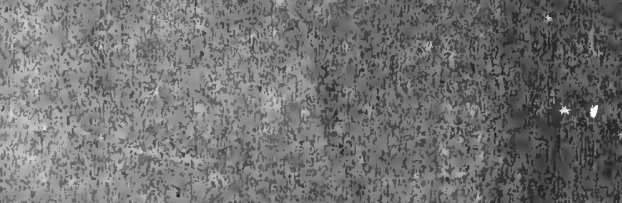
. ind 1.t. tas 